\title{
Biomolecular Evidence of Early Human Occupation of a High-Altitude Site in Western Central Asia During the Holocene
}

\begin{abstract}
Natalie Schroeter ${ }^{1}$, Stefan Lauterbach ${ }^{2}$, Martina Stebich $^{3}$, Julia Kalanke ${ }^{4}$, Jens Mingram ${ }^{4}$, Caglar Yildiz ${ }^{5}$, Stefan Schouten ${ }^{5,6}$ and Gerd Gleixner ${ }^{1 *}$

${ }^{1}$ Research Group Molecular Biogeochemistry, Max Planck Institute for Biogeochemistry, Jena, Germany, ${ }^{2}$ Leibniz Laboratory for Radiometric Dating and Stable Isotope Research, Kiel University, Kiel, Germany, ${ }^{3}$ Senckenberg Research Institute and Natural History Museum Frankfurt - Research Station of Quarternary Palaeontology, Weimar, Germany, ${ }^{4}$ Section 4.3 - Climate Dynamics and Landscape Evolution, GFZ German Research Centre for Geosciences, Potsdam, Germany, ${ }^{5}$ Department of Marine Microbiology and Biogeochemistry, NIOZ Royal Netherlands Institute for Sea Research, Texel, Netherlands, ${ }^{6}$ Department of Earth Sciences, Faculty of Geosciences, Utrecht University, Utrecht, Netherlands
\end{abstract}

OPEN ACCESS

Edited by:

Karen L. Bacon,

National University of Ireland Galway,

Ireland

Reviewed by:

Fabien Arnaud,

Centre National de la Recherche

Scientifique (CNRS), France

Nadia Solovieva,

University College London,

United Kingdom

${ }^{*}$ Correspondence:

Gerd Gleixner

gerd.gleixner@bgc-jena.mpg.de

Specialty section:

This article was submitted to

Quaternary Science, Geomorphology

and Paleoenvironment,

a section of the journal

Frontiers in Earth Science

Received: 09 September 2019

Accepted: 22 January 2020

Published: 07 February 2020

Citation:

Schroeter N, Lauterbach S, Stebich M, Kalanke J, Mingram J,

Yildiz C, Schouten S and Gleixner G (2020) Biomolecular Evidence of Early Human Occupation of a High-Altitude

Site in Western Central Asia During the Holocene. Front. Earth Sci. 8:20.

doi: 10.3389/feart.2020.00020
Reconstructions of early human occupation of high-altitude sites in Central Asia and possible migration routes during the Holocene are limited due to restricted archeological sample material. Consequently, there is a growing interest in alternative approaches to investigate past anthropogenic activity in this area. In this study, fecal biomarkers preserved in lake sediments from Lake Chatyr Kol (Tian Shan, Kyrgyzstan) were analyzed to reconstruct the local presence of humans and pastoral animals in this lowhuman-impact area in the past. Spanning the last $\sim 11,700$ years, this high-altitude site ( 3,500 $\mathrm{m}$ above sea level) provides a continuous record of human occupancy in Western Central Asia. An early increase of human presence in the area during the mid-Holocene is marked by a sharp peak of the human fecal sterol coprostanol and its epimer epicoprostanol in the sediments. An associated increase in $5 \beta$-stigmastanol, a fecal biomarker deriving from herbivores indicates a human occupancy that most probably largely depended upon livestock. However, sterol profiles show that grazing animals had already occupied the catchment area of Lake Chatyr Kol before and also after a significant presence of humans. The biomarker evidence in this study demonstrates an early presence of humans in a high-altitude site in Central Asia at 2,900-4,000 a BP. Dry environmental conditions during this period likely made high altitude regions more accessible. Moreover, our results help to understand human migration in Western Central Asia during the early and mid-Holocene as part of a prehistoric Silk Road territory.

Keywords: fecal stanols, geochemistry, paleodemography, lake sediments, biomarkers, Silk Road

\section{INTRODUCTION}

There is growing evidence that human occupation of high-altitude sites [ $>3,500 \mathrm{~m}$ above sea level (a.s.l.)] has occurred as early as during the latest Pleistocene and Early Holocene (Brantingham et al., 2013; Rademaker et al., 2014; Shnaider S. et al., 2018; Zhang et al., 2018). The highest located and oldest archeological sites have so far been identified on the Tibetan Plateau and in the southern Peruvian Andes, dating back to at least 30,000 and > 11,500 years ago, respectively 
(Rademaker et al., 2014; Zhang et al., 2018). Recently, however, Ossendorf et al. (2019) provided evidence of repeated human occupation of Fincha Habera ( 3,500 m a.s.l.), located in Africa's largest alpine landscape, dating back to 47,000-31,000 years ago, which makes it the earliest known high-altitude residential site. These findings indicate that prehistoric human populations were able to adapt to climatic and environmental extremes at high altitudes, such as low temperatures, high solar radiation and low primary productivity, as well as to related physiological challenges, including hypoxia and cold stress (Rademaker et al., 2014; Meyer et al., 2017). The prehistoric settlement of highaltitude regions was likely facilitated by strong immigration from one resource area to another, and/or by biological adaptation to a variable climate and environment (Madsen et al., 2006). In this context, a key period in human history was the onset of the Holocene since the development of more favorable climate conditions promoted both the rise and decline of many prehistoric civilizations (Dong et al., 2012; Thienemann et al., 2017). Additionally, demographic pressure on resources potentially opened previously uninhabitable highaltitude regions, such as the mountain regions of Central Asia, for settlement and migration.

Owing to its location at the crossroads between East and West and the related importance for migration and cultural exchanges (Agatova et al., 2014) for early humans and later as part of the ancient Silk Road, Central Asia has recently become a focus region with respect to investigating the occupation of high-altitude regions by early human civilizations (Bae et al., 2017; Hessl et al., 2017; Shnaider S. et al., 2018; Yang et al., 2019a). Due to the harsh environment, featuring dry deserts, cold mountains and seasonal grasslands, a nomadic pastoral culture has predominantly prevailed in the mountainous regions of Arid Central Asia, which is contrary to Monsoon Asia where sedentary agriculturalists predominated (Hessl et al., 2017; Yang et al., 2019b). Despite its crucial role in cultural development and human migration patterns, little is known about the early history of human occupation of Western Central Asia as part of the Silk Road territory, especially during the period between the Paleolithic and the mid-Holocene (Shnaider S. V. et al., 2018). Western Central Asia encompasses several high-altitude mountain regions, such as the Tian Shan, the Pamir Mountains and the Alay Mountains (Shnaider S. et al., 2018). There is evidence that the Alay Mountains may represent the high-altitude region in Western Central Asia that has at first been occupied by humans and was at least temporarily inhabited by huntergatherers since the Paleolithic (Ranov, 1975; Abdykanova, 2014; Shnaider S. et al., 2018; Taylor et al., 2018). However, the early colonization of high-altitude Central Asia by humans is still not well-constrained (Rademaker et al., 2014). Generally, the success of tracing human presence in such regions largely relies on finding related archeological sites and respective artifacts. However, as this is often hindered by a limited number of settlements and small sample sizes, there has been a growing interest in alternative approaches to detect early anthropogenic activity. In this context, the identification of sterols and stanols as fecal biomarkers is an emergent valuable analytical tool that can provide evidence for the presence of both humans and livestock at a certain site. Fecal sterols and stanols are recalcitrant organic compounds, which can accumulate and persist in sediments for 1000s of years (Bull et al., 2001,

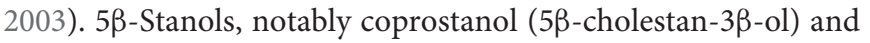
$5 \beta$-stigmastanol ( $24 \beta$-ethyl- $5 \beta$-cholestan- $3 \beta$-ol), are the products of anaerobic microbial reduction of sterols, i.e., cholesterol (Cholest-5-en-3 $\beta$-ol), in the intestinal tract of mammals (Eyssen et al., 1973; Macdonald et al., 1983). Owing to their herbivorous diet, ruminant feces are largely composed of $5 \beta$ - stigmastanol and epi-5 $\beta$-stigmastanol ( $24 \beta$-ethyl-5 $\beta$-cholestan- $3 \alpha$-ol), which are derived from $\beta$-sitosterol (3 $\beta$-Stigmast-5-en-3-ol) and stigmasterol (Stigmasta-5,22-dien-3 $\beta$-ol), the most common and the third most common phytosterol (plant sterol), respectively (Evershed et al., 1997; Bull et al., 2002; Rogge et al., 2006). Conversely, coprostanol, a cholesterol derivative, accounts for $\sim 60 \%$ of the total sterols in human feces (Leeming et al., 1996; Bull et al., 2002; Daughton, 2012). Therefore, human fecal input can be distinguished from those of herbivores (Leeming and Nichols, 1996; Leeming et al., 1996; Ortiz et al., 2016), enabling their use in paleoenvironmental and archeological studies (e.g., Baeten et al., 2012; D’Anjou et al., 2012; Gea et al., 2017; Engels et al., 2018; White et al., 2018).

Since sterols and stanols are well-preserved in lacustrine sediments, the latter provide an ideal natural archive for tracing the sources of feces in the environment and for assessing human and livestock occupation of a certain area through time, both qualitatively and quantitatively (D'Anjou et al., 2012; White et al., 2018; Kinder et al., 2019). Furthermore, the vicinity of lakes and rivers provides ideal conditions for natural settlements as well as important pathways for human migration (Thienemann et al., 2017).

In this study we analyzed coprostanol, epicoprostanol, cholesterol, cholestanol and $5 \beta$-stigmastanol as fecal biomarkers in the sediments of Lake Chatyr Kol, in the central Tian Shan of Kyrgyzstan to elucidate the local presence of humans and livestock during the Holocene. Investigating the history of human occupation of this part of the Tian Shan can potentially contribute to a better understanding of its cultural importance as a prehistoric trade and migration route along the ancient Silk Road.

\section{Study Area}

Lake Chatyr Kol $\left(40^{\circ} 37^{\prime} \mathrm{N}, 75^{\circ} 18^{\prime} \mathrm{E}\right)$ is located at $3,535 \mathrm{~m}$ a.s.l. in the southern Tian Shan of Kyrgyzstan, close to the border to China (Figure 1). The lake occupies the south-western part of a large intra-montane basin between the At Bashy Range in the north and the Torugart pass in the south. To the west of Lake Chatyr Kol lies the Arpa river valley and moraine landscape. Lake Chatyr Kol is the third largest lake in Kyrgyzstan (Thorpe et al., 2009) and has a catchment area of approximately $1,084 \mathrm{~km}^{2}$. The lake extends to a maximum width (NW-SE) of $12 \mathrm{~km}$ and a maximum length (SW-NE) of $23 \mathrm{~km}$ and has a surface water area of $\sim 175 \mathrm{~km}^{2}$ (Mosello, 2015). Since Lake Chatyr Kol is a hydrologically closed alpine lake, the lake water is slightly brackish (salinity $1.18 \mathrm{~g} / \mathrm{l}$ in July 2018) and its water balance is generally controlled by the interplay between snow meltwater and precipitation input and evaporation. The largest and only permanent inflow is the Kekagyr River, which enters 


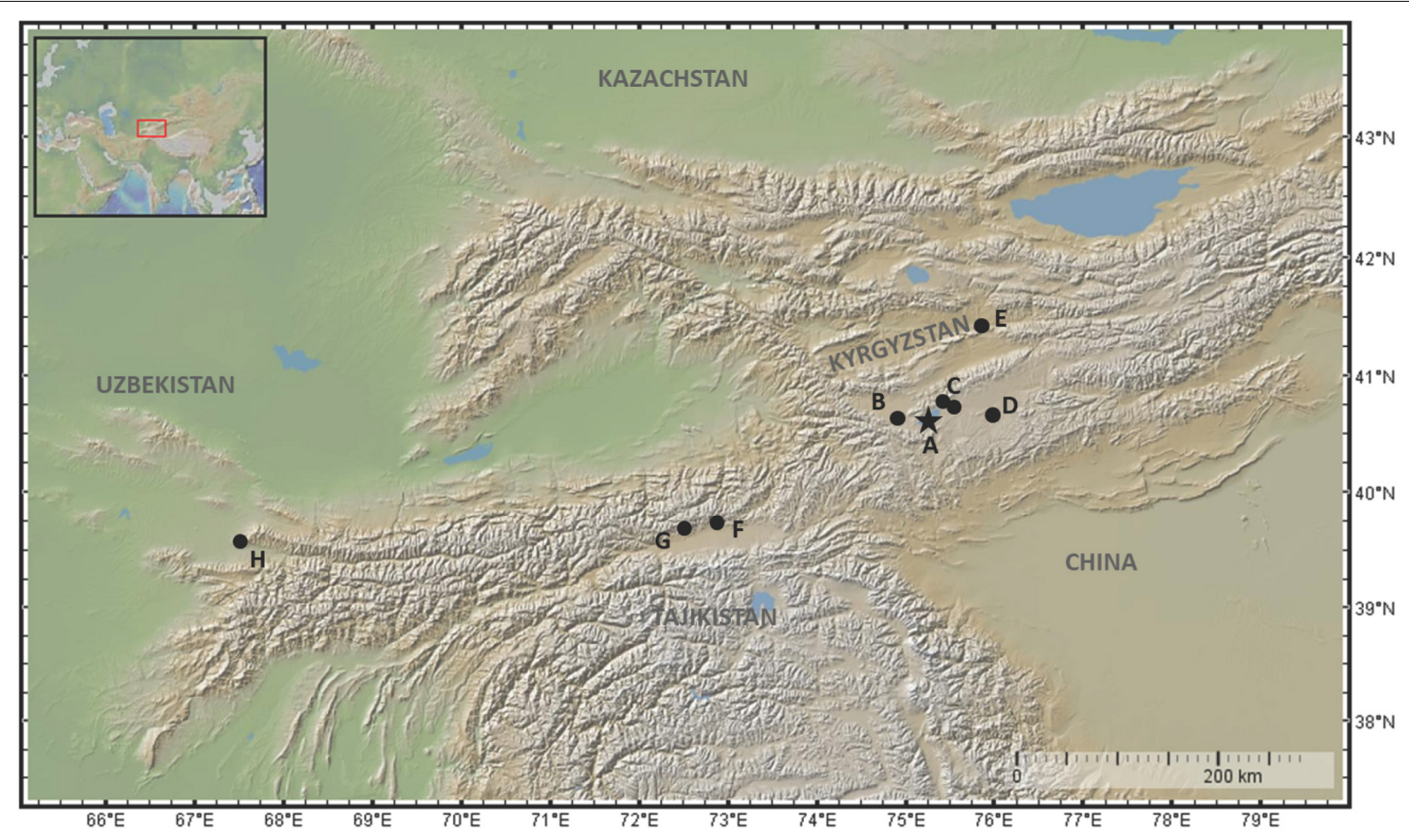

FIGURE 1 | Map of Central Asia showing the study site Lake Chatyr Kol (indicated by a black star) and other sites mentioned in this study. A = Lake Chatyr Kol; B = Grotto Semetey (Abdykanova, 2014); C = Kok-Aygyr (Ranov and Kydyrov, 1969); D = Terek-1 (Ranov, 1975); E = Aigyrzhal-2 (Motuzaite Matuzeviciute et al., 2017); F = Alay Valley (Shnaider S. et al., 2018); G = Chegirtke Cave (Taylor et al., 2018); H = Sarazm (Spengler and Willcox, 2013). Figure made with GeoMapApp (www.geomapapp.org, Ryan et al., 2009).

the lake from the north-east. The present-day regional climate is temperate continental (Wang et al., 2017) and dominated by the interaction between the Siberian anticyclonic circulation and the mid-latitude Westerlies (Aizen et al., 1997; Lauterbach et al., 2014). Owing to the high mountain ranges of the Tian Shan that prevent the transport of moisture, rainfall is reduced, especially in January and February (Aizen et al., 1995, 2001). Mean annual precipitation consequently amounts to only $\sim 300 \mathrm{~mm} / \mathrm{a}$ (Koppes et al., 2008). The mean annual air temperature (1961-1990) in Naryn, $\sim 100 \mathrm{~km}$ northeast of Lake Chatyr Kol, is $-0.34^{\circ} \mathrm{C}$ (Ilyasov et al., 2013) and the lake is generally ice covered from October to April. The prevailing dry and cold conditions favor the preservation of permafrost soils (Shnitnikov et al., 1978) and thermokarst formations can be frequently observed in this region (Abuduwaili et al., 2019). Due to the harsh climate conditions, vegetation is sparse and classified as desert and semi-desert vegetation. Alpine grasslands dominate this region (Taft et al., 2011) and there are no trees in the surrounding of the lake.

\section{MATERIALS AND METHODS}

\section{Sediment Material and Chronology}

In July/August 2012, several vertically overlapping, 2-m-long sediment cores have been recovered from about $20 \mathrm{~m}$ water depth in the deep south-western part of Lake Chatyr Kol $\left(40^{\circ} 36.37^{\prime} \mathrm{N}, 75^{\circ} 14.02^{\prime} \mathrm{E}\right)$ by using a $60 \mathrm{~mm}$ diameter UWITEC piston corer. Additionally, seven parallel gravity cores have been withdrawn in 2017 by utilizing a UWITEC gravity corer with hammer weight (SC17_1-7). The individual sediment cores were stratigraphically linked using distinct macroscopically visible correlation layers, allowing the construction of a continuous, 623.5-cm-long composite profile (Kalanke et al., Under review). With the exception of the upper $63 \mathrm{~cm}$, the sediments are almost continuously annually laminated (varved). The floating varve age model (Figure 2), labeled "Chatvd19," was established using replicate microscopic varve counts below $63.0 \mathrm{~cm}$ depth, which were performed on petrographic thin sections (Kalanke et al., Under review) prepared at the GFZ German Research Centre for Geosciences, Potsdam, Germany. Replicate varve counts yield a mean deviation of $\sim 5 \%$ which was applied as an uncertainty for the varved composite profile between 623.5$63.0 \mathrm{~cm}$ depth. The uppermost homogenous $63.0 \mathrm{~cm}$ of the composite profile were chronologically constrained by gamma spectrometric analysis of ${ }^{210} \mathrm{~Pb}$ and ${ }^{137} \mathrm{Cs}$ performed at the GFZ German Research Centre for Geosciences, Potsdam, Germany, on $0.5 \mathrm{~cm}$ thick sediment slices of the parallel gravity core SC17_7. ${ }^{210} \mathrm{~Pb}$ activity concentrations were used for age model constructions based on a constant initial concentration (CIC) model (cf. Appleby, 2002) and on a constant rate of supply (CRS) model (Appleby and Oldfield, 1978) in combination with ${ }^{137} \mathrm{Cs}$ activity concentrations. Both ${ }^{210} \mathrm{~Pb}$ models are in good accordance with the onset of elevated ${ }^{137} \mathrm{Cs}$ activity concentrations, representing the onset of global nuclear weapon 


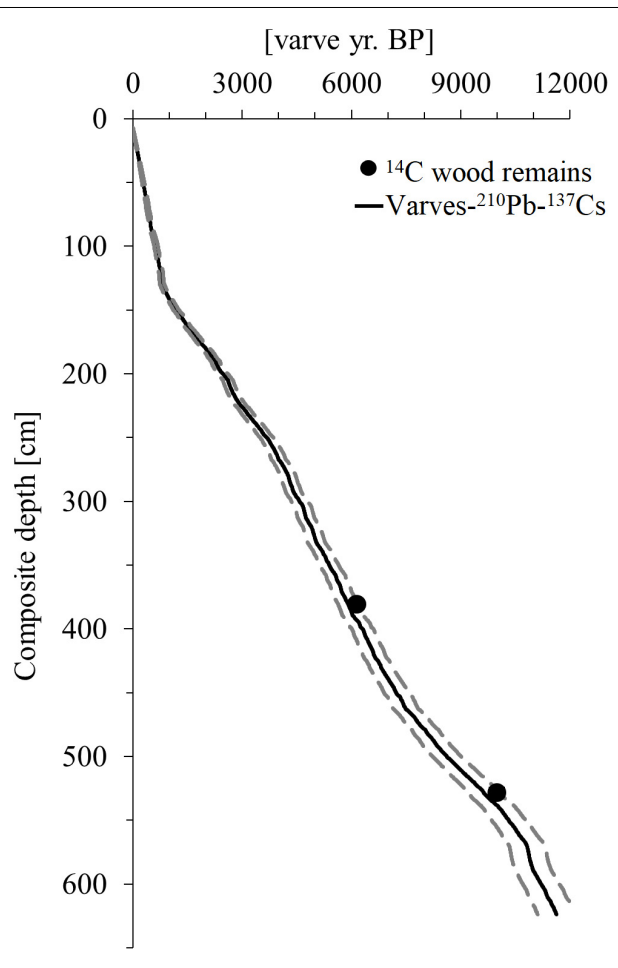

FIGURE 2 | Age model of the Lake Chatyr Kol sediment record (Kalanke et al., Under review). The age model (black line) is based on varve counting combined with ${ }^{210} \mathrm{~Pb}$ and ${ }^{137} \mathrm{Cs}$ measurements. Dashed lines indicate the varve counting error (Kalanke et al., Under review). Black dots with $2 \sigma$ error ranges represent $\mathrm{AMS}{ }^{14} \mathrm{C}$ dates of terrestrial plant macro remains.

tests since AD 1945 (Kudo et al., 1998; Wright et al., 1999). The non-varved interval between the time marker AD 1945 and the onset of varve deposition at $63.0 \mathrm{~cm}$ depth was interpolated by using a mean sedimentation rate derived from varve thickness measurements of adjacent varved intervals with an assumed uncertainty of $10 \%$. The final floating varve chronology had a basal age of $11619 \pm 603$ a BP and was independently verified by two AMS ${ }^{14} \mathrm{C}$ ages of terrestrial wood remains at a composite depth of 380.5 and $528 \mathrm{~cm}$ (Poz-63307 and Poz-54302) (Kalanke et al., Under review). AMS ${ }^{14} \mathrm{C}$ measurements were conducted at the Pozńan Radiocarbon Laboratory in Poland and the conventional ${ }^{14} \mathrm{C}$ ages were calibrated with OxCal 4.3 (Bronk Ramsey, 1995) using the IntCal13 calibration curve (Reimer et al., 2013). All age dates of Lake Chatyr Kol samples reported in this study refer to the described age model.

\section{Pollen Analyses}

Pollen analyses have been carried out on 152 sediment samples. The samples have been collected volumetrically (ranging between $1-2.6 \mathrm{~cm}^{3}$ ) at intervals of $4 \mathrm{~cm}$ on average from sediment depth between 0.5 and $623 \mathrm{~cm}$. The preparation involved treatment with $\mathrm{HCl}, \mathrm{KOH}, \mathrm{HF}$, hot acetolysis mixture and ultrasonic sieving (mesh size $6 \times 8 \mu \mathrm{m}$ ), following the standard methods described by Berglund and Ralska-Jasiewiczowa (1986). Lycopodium spores were added to each sample to calculate the pollen concentrations. Sample residues were stained with safranine, mounted in glycerine and analyzed using an Olympus BX 40 light microscope at $\times 400-1000$ magnification. With the exception of six samples, a minimum of 500 terrestrial pollen grains was counted. The identification of the palynomorphs was carried out with the aid of the palynological reference collection of the Senckenberg Research station of Quaternary Palaeontology, Weimar, supported by different pollen atlases (Beug, 2004; Reille, 1995-1999). Pollen percentages were calculated on the basis of terrestrial pollen, excluding aquatics, spores and non-pollen palynomorphs.

\section{Fecal Biomarker Analyses}

For the present study, bulk sediment samples of $1 \mathrm{~cm}$ thickness were taken from the Lake Chatyr Kol composite profile at $5 \mathrm{~cm}$ intervals and subsequently freeze-dried. The freezedried bulk sediment samples were homogenized and lipids were extracted twice with a dichloromethane/methanol solvent mixture (9:1, v:v) by using a pressurized solvent speed extractor (E-916, BÜCHI, Essen, Germany) operated at $100^{\circ} \mathrm{C}$ and 120 bar for $15 \mathrm{~min}$. Subsequently, the total lipid extract of each sample was partitioned into a neutral and an acid fraction by elution over aminopropyl gel columns (CHROMABOND ${ }^{\circledR} \mathrm{NH}_{2}$ polypropylene columns, $60 \AA$ A, Macherey-Nagel GmbH \& Co., KG, Düren, Germany) with dichloromethane/isopropanol (3:1, $\mathrm{v}: \mathrm{v})$ and diethyl ether:acetic acid (19:1, v:v), respectively (Richey and Tierney, 2016). The neutral fraction was further separated over activated silica gel columns ( 2 g, 0.040-0.063 mm mesh, Merck, Darmstadt, Germany) into hydrocarbons, ketones and a polar fraction by elution with hexane, dichloromethane and methane, respectively. The hydrocarbon fraction, containing long-chain $n$-alkanes, was analyzed using a gas chromatograph (GC) with flame ionization detection (GC-FID, Agilent 7890B GC) and an Ultra 2 column (50 m length, $0.32 \mathrm{~mm} \mathrm{ID,}$ $0.52 \mu \mathrm{m}$ film thickness, Agilent Technologies, Santa Clara, CA, United States). The GC oven temperature program started at $140^{\circ} \mathrm{C}$ (hold for $1 \mathrm{~min}$ ), heated up to $310^{\circ} \mathrm{C}$ at $4^{\circ} \mathrm{C} / \mathrm{min}$ (hold for $15 \mathrm{~min}$ ) and finally increased to $325^{\circ} \mathrm{C}$ at $30^{\circ} \mathrm{C} / \mathrm{min}$ (hold for $3 \mathrm{~min})$. The PTV injector was operated in splittless mode and started at $45^{\circ} \mathrm{C}$ (hold for $0.1 \mathrm{~min}$ ) and increased to $300^{\circ} \mathrm{C}$ at $14.5^{\circ} \mathrm{C} / \mathrm{s}$ (hold for $3 \mathrm{~min}$ ). The quantification of long-chain $n$-alkanes was carried out by peak area comparison with an external $n$-alkane standard mixture $\left(n \mathrm{C}_{15}-n \mathrm{C}_{33}\right)$.

The polar fraction, containing sterols and stanols, was silylated with $10 \mu \mathrm{L} \mathrm{N}, \mathrm{O}$-bis(trimethylsilyl)trifluoroacetamide (BSTFA) and $10 \mu \mathrm{L}$ pyridine at $60^{\circ} \mathrm{C}$ for $30 \mathrm{~min}$ and afterward dissolved in ethyl acetate. Sterol and stanol concentrations were measured at the Royal Netherlands Institute for Sea Research (NIOZ), Texel, Netherlands, as described by de Bar et al. (2019). Gas chromatographic separation was carried out utilizing an Agilent 7890B GC that was equipped with a fused silica capillary column (Agilent CP Sil-5, length $25 \mathrm{~m}$, diameter $320 \mu \mathrm{m}$, film thickness $0.12 \mu \mathrm{m}$ ) and coupled to an Agilent 5977A MSD mass spectrometer (MS). The GC temperature program started at $70^{\circ} \mathrm{C}$, increased to $130^{\circ} \mathrm{C}$ at a rate of $20^{\circ} \mathrm{C} / \mathrm{min}$, then heated to $320^{\circ} \mathrm{C}$ at $4^{\circ} \mathrm{C} / \mathrm{min}$ and was held at $320^{\circ} \mathrm{C}$ for $25 \mathrm{~min}$. The flow rate was $2 \mathrm{~mL} / \mathrm{min}$. The MS quadrupole was held at $150^{\circ} \mathrm{C}$ 
and the electron impact ionization energy of the MS source was set to $70 \mathrm{eV}$. Sterols were identified and quantified via single ion monitoring (SIM) of the mass-to-charge-ratios $\mathrm{m} / \mathrm{z}$ 368.3 (cholesterol), 398.3 (stigmastanol) and 370.3 (cholestanol). Additionally, characteristic mass spectra fragmentation patterns and relative retention times were compared with the literature for further identification. Coprostanol and epicoprostanol were additionally confirmed using reference standards. An external coprostanol reference standard in five different concentrations was used for quantification of the sterols.

In order to account for microbial degradation processes, we applied the ratio established by Bull et al. (1999):

$$
\frac{\text { coprostanol }+ \text { epicoprostanol }}{\text { coprostanol }+ \text { epicoprostanol }+5 \alpha-\text { cholestanol }}=\mathrm{R} 1
$$

$5 \alpha$-cholestanol is a product of the degradation of cholesterol by soil microbial communities (Wakeham, 1989; Bull et al., 2001). Therefore, considering both $5 \alpha$-cholestanol and coprostanol allows to compare input and preservation of stanols in a specific environment to stanol input from feces (White et al., 2018). In particular, higher R1 values indicate increased human fecal input, while lower R1 values reflect low human fecal deposition.

In addition, we utilized the ratio proposed by Evershed and Bethell (1996) to distinguish between human and higher mammal feces:

$$
\frac{\text { coprostanol }}{5 \beta-\text { stigmastanol }}=\mathrm{R} 2
$$

with R2 values $>1.5$ suggesting human or porcine fecal matter (Evershed and Bethell, 1996).

In order to determine distinct temporal intervals in the Lake Chatyr Kol sediment record, we used Uniform Manifold Approximation and Projection (UMAP), a novel nonmetric manifold learning technique for dimension reduction (McInnes et al., 2018) implemented in R 3.6 as package "umap" 0.2.3.1 (Konopka, 2019; R Core Team, 2019). UMAP was recently shown to preserve more of the global structure compared to previous nonmetric techniques such as t-SNE (van der Maaten and Hinton, 2008; McInnes et al., 2018). The improved preservation of global structures in UMAP allowed the use of $\mathrm{k}$-means clustering on the resulting graph. We supplied the UMAP algorithm with the biomarker profiles as well as their chronology and interpreted the resulting three clusters as distinct temporal intervals in the sediment core (Phases I, II, and III) (Supplementary Figure S1). Data visualizations were performed in R package "ggplot2" 3.2.1 (Wickham, 2016).

\section{RESULTS AND DISCUSSION}

\section{Vegetation Development}

The Holocene vegetation development of Lake Chatyr Kol has been derived from 152 pollen samples collected between 0.5 and $623 \mathrm{~cm}$ composite core depth. The sampling intervals yield a temporal resolution of 77 years on average. Total pollen concentration is circa $30,000-60,000$ grains per $\mathrm{cm}^{3}$ through most of the sequence. Overall, 83 pollen taxa were distinguished, consisting of 20 arboreal and 63 non-arboreal elements. The pollen assemblages are characterized by predominance of nonarboreal taxa contributing between 88.3 and $99.6 \%$ to the terrestrial pollen assemblage (Supplementary Table S1). The herbaceous flora is mainly composed of Artemisia (34-61\%), Chenopodiaceae (15-29\%), Poaceae (7-24\%), and Cyperaceae $(0.2-6.9 \%)$. Other herbs occur in smaller quantities or only scattered, each contributing between 0 and $8 \%$. Most abundant woody taxa are Juniperus (0-6.6\%), Betula (0-3.4\%), Hippophaë (0-1.8\%) and Picea (0-1.7\%), while other tree pollen taxa appear in trace amounts (Supplementary Table S1).

The dominance of xerophytic herbs and the sparse representation of trees and shrubs reveal an open landscape character in the surroundings of the Chatyr Kol Lake throughout the Holocene (Figure 3). According to studies on modern pollen assemblages in central and eastern Asia, herbaceous pollen composition of the Chatyr Kol Lake sediments mainly reflects semi-arid, alpine meadow, steppe, and lake shore communities (Beer et al., 2007; Ma et al., 2008; Qin et al., 2015). In terms of the overall species composition, the pollen signatures show only gradual changes through the entire record. Therefore, the alpine landscape of the study region experienced no major vegetation shifts during the past $11.5 \mathrm{ka}$.

\section{Sedimentary Fecal Biomarker Distribution}

Several fecal biomarkers were detected in the Lake Chatyr Kol sediments of which five sterols and stanols, i.e., cholesterol, coprostanol, epicoprostanol, 5 $\beta$-stigmastanol and $5 \alpha$-cholestanol, were quantified. Their total sum reveals a strong increase from relatively low concentrations in the oldest part of the composite profile $[\sim 146 \mu \mathrm{g} / \mathrm{g}$ dry weight (d.w.)] to higher amounts $(5,342 \mu \mathrm{g} / \mathrm{g}$ d.w. $)$ at a composite depth of $319.5 \mathrm{~cm}(\sim 4,900$ a BP) (Figure 3). The total concentration of sterols and stanols ranged between 0.2 and 5,800 $\mu \mathrm{g} / \mathrm{g} \mathrm{d}$.w. The most abundant sterol throughout the record is cholesterol (46\%), followed by $5 \beta$-stigmastanol $(21 \%)$.

The sediment record was divided into three distinct phases based on three distinct $\mathrm{k}$-means clusters within a UMAP ordination of the fecal biomarker data (Figure 4 and Supplementary Figure S1). Phase I $(\sim 11,400-8,300$ a BP) shows conditions of prehuman occupation with low background concentrations of human-specific fecal sterols and stanols (coprostanol, epicoprostanol, and cholesterol). However, considerable amounts of $5 \alpha$-cholestanol and $5 \beta$-stigmastanol are present throughout Phase I, indicating the presence of indigenous higher mammals. First noticeable human activity is recorded during Phase II ( 7,600-2,400 a BP), which is characterized by strong concentration increases in all fecal biomarkers at three time points, dating to $\sim 5,900, \sim 4,800$, and $\sim 2,400$ a $\mathrm{BP}$, respectively. This phase represents the beginning of human occupation in the catchment area of Lake Chatyr Kol, possibly with domesticated livestock, since both human-specific and higher mammals-specific fecal biomarkers increase significantly during Phase II. In relation to the total amount of fecal 


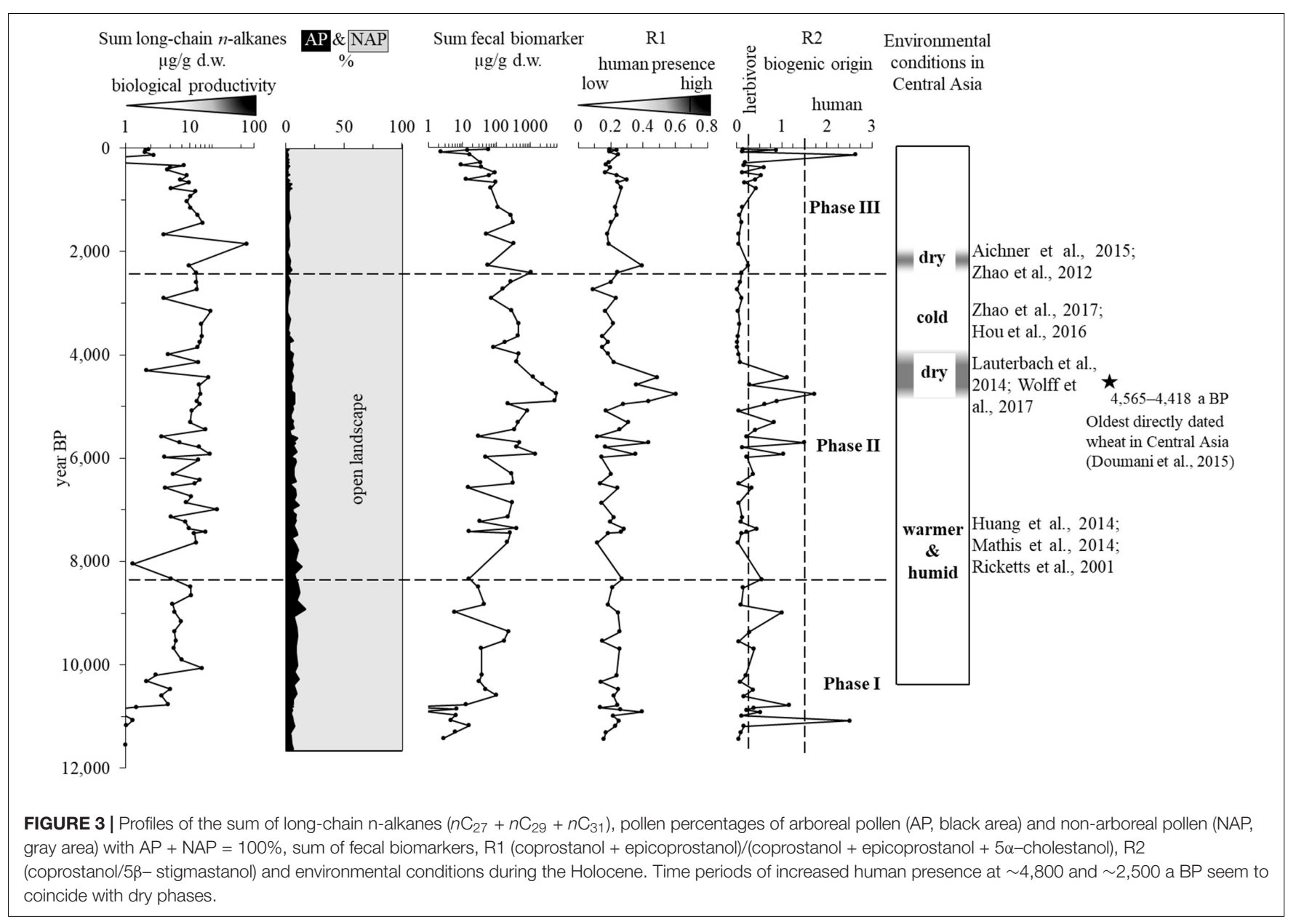

biomarkers, the imprint of human presence was highest at $\sim 4,800$ a BP, where concentrations reach their maxima. Additionally, there are intervals within Phase II, which show decreased values of human-specific fecal biomarkers, especially during $\sim 3,800$ $-2,700$ a BP, whereas concentrations of $5 \beta$-stigmastanol are still elevated. The beginning of Phase III $(<2,300$ a BP) is marked by a decline of all biomarkers toward background concentrations comparable to Phase I. Phase III continues to modern times and displays the current low level of human occupation of the catchment area of Lake Chatyr Kol.

\section{Sources of Analyzed Fecal Biomarkers}

In order to disentangle the sources of the sterols and stanols, we applied principal component analysis (PCA). PC1 and PC2 account for $96.2 \%$ of the total variance and show a clear distinction between the fecal biomarkers cholesterol, coprostanol and epicoprostanol, which are associated to a carnivorous and omnivorous diet, and the herbivore-derived fecal biomarker $5 \beta$ stigmastanol (Figure 5). We utilized cholesterol, coprostanol and epicoprostanol as human-specific biomarkers; however it is possible that carnivorous animals may have contributed to this biomarker signal. The strong linear correlation between the concentrations of coprostanol and epicoprostanol $\left(r^{2}=0.9\right)$ and coprostanol and cholesterol $\left(r^{2}=0.92\right)$ additionally confirms a combined source of these compounds (Supplementary Figure S2). This confirms coprostanol, epicoprostanol, and cholesterol as human biomarkers and $5 \beta$-stigmastanol as being indicative of grazing animals including domesticated livestock.

Since $5 \beta$-stanol background concentrations are also detectable in soils that were not exposed to fecal deposition, diagnostic ratios of selected sterols that are independent of total concentrations are advantageous for the interpretation of the total fecal biomarker spectrum (Grimalt et al., 1990; Bull et al., 1999, 2001). In this context, several ratios of different sterol and stanol classes have been proposed to determine the origin of organic matter and to detect anthropogenic activity (Grimalt et al., 1990; Bull et al., 2002; Martins et al., 2007). In order to determine the fecal origin of our sterols and stanols, we applied ratio R1 proposed by Bull et al. (1999). By including epicoprostanol, R1 corrects for microbial degradation processes since coprostanol may be microbially degraded in situ to epicoprostanol (Bull et al., 1999, 2002; Battistel et al., 2015).

R1 values for the sediments of Lake Chatyr Kol range between 0.09 and 0.6 (Figure 3). A R1 value of 0.7 has been proposed as a threshold with higher R1 values indicating human fecal deposition and lower values reflecting scarce human presence (Grimalt et al., 1990). The values in the Lake Chatyr Kol sediments, however, do not exceed this threshold but as it was 


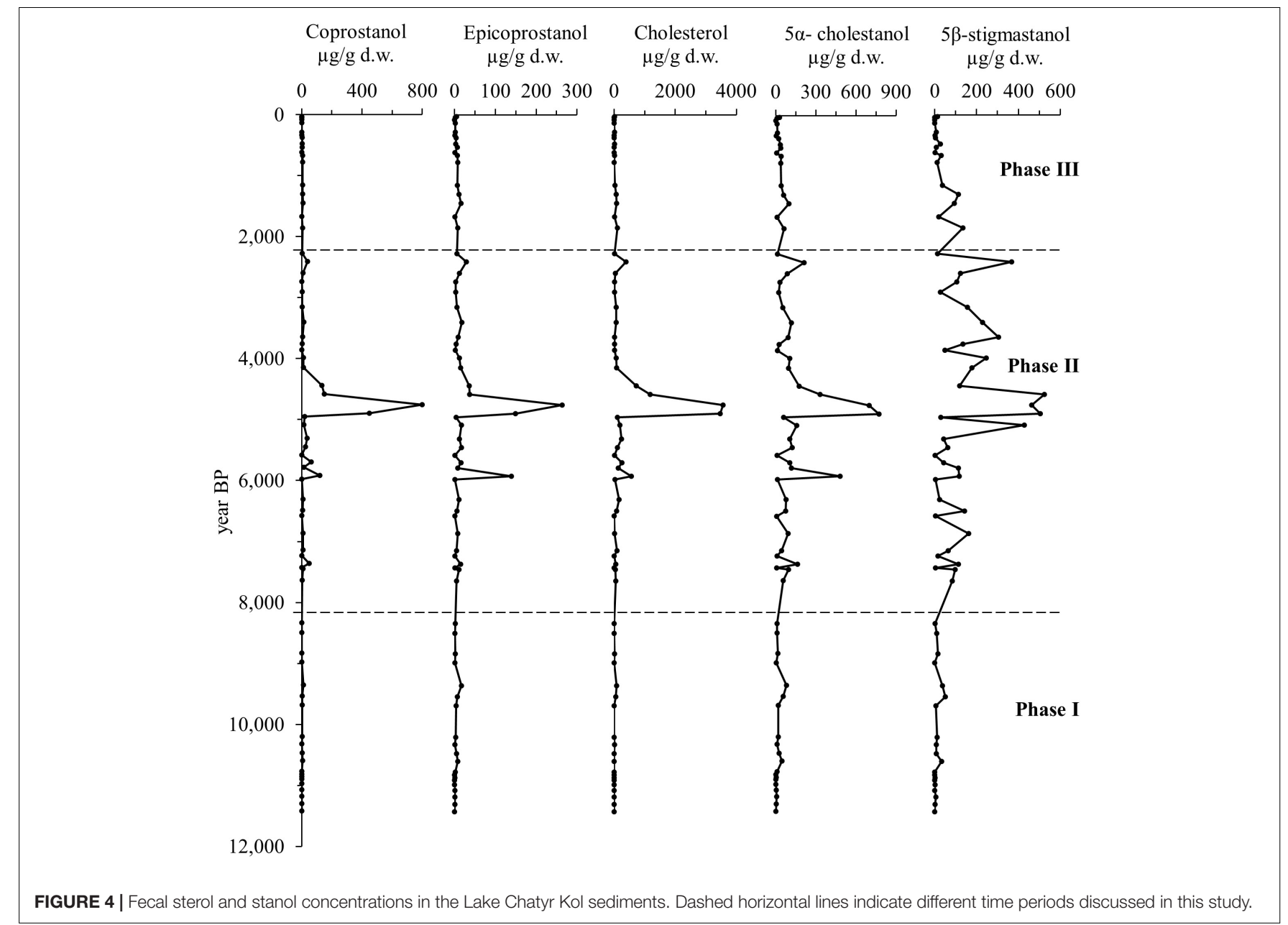

originally determined from modern-day urban sewage pollution investigations, it may not be applicable in an archeological context (Bull et al., 2001; Birk et al., 2011; Baeten et al., 2012). Nevertheless, elevated R1 values during Phase II, especially at $\sim 4,800$ a BP $(\mathrm{R} 1=0.6)$, demonstrate the fecal nature of the $5 \beta$-stanols and most likely indicate the presence of humans during the mid-Holocene (Figure 3).

To allow for the discrimination between human and herbivore fecal deposition, the ratio of coprostanol and $5 \beta$-stigmastanol (R2) was established (Evershed and Bethell, 1996), which is based on the divergent biogenic origin of these $5 \beta$-stanols. As a result of their herbivorous diet and the associated high uptake of phytosterols, ruminant feces are enriched in $5 \beta$-stigmastanol, whereas coprostanol is the major sterol in human and omnivore feces. Typically, R2 values between 1.5 and 5.5 are indicative of humans and pigs, while $\mathrm{R} 2$ values in the order of $\sim 0.25$ imply herbivorous fecal input (Baeten et al., 2012).

R2 values in the Lake Chatyr Kol sediment record fluctuate between 0.003 and 2.6 (Figure 3). Highest R2 values of 2.5 and 2.6 are observed at $\sim 11,100$ and $\sim 132$ a BP, respectively (Figure 3 ). However, these values are controlled by particularly low amounts of $5 \beta$-stigmastanol and may therefore not necessarily reflect human activity. Conversely, slightly elevated R2 values (>1.5) during Phase II at $\sim 5,700$ and $\sim 4,800$ a $\mathrm{BP}$ confirm a human origin of the stanols and reinforce the assumption of an early human occupation of the Lake Chatyr Kol catchment area during the mid-Holocene. In this context, generally lower R2 values during Phase I and Phase III indicate predominant herbivore origin of the stanols during the Early and Late Holocene, respectively (Figure 3).

\section{Holocene Human and Mammal Presence in the Lake Chatyr Kol Catchment Area Phase I ( 11.4k - 8,300 a BP)}

The beginning of the Holocene was characterized by a global temperature rise (Marcott et al., 2013). Such more favorable climate conditions may have boosted human migration as climate is generally considered a key factor for cultural and social development (DeMenocal, 2001; Flohr et al., 2016). Direct evidence of human occupation of Kyrgyzstan during this period was observed in the western part of the Alay Valley in southern Kyrgyzstan at an elevation of $\sim 2,800 \mathrm{~m}$ a.s.l. (Shnaider S. et al., 2018), where findings of stone tool assemblages suggest the local presence of prehistoric humans during the Late Pleistocene or Early Holocene, supposedly mainly 


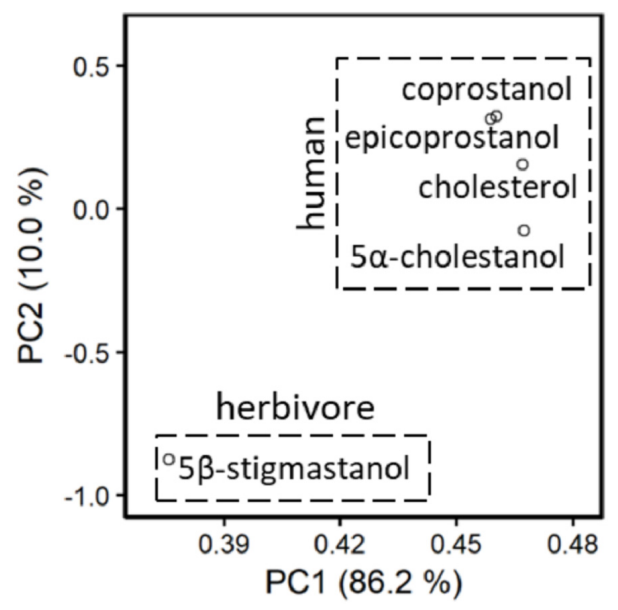

FIGURE 5 | Principal component analysis (PCA) of fecal sterols. The separation indicates different sources for coprostanol, epicoprostanol, cholesterol, $5 \alpha$-cholestanol, and $5 \beta$ - stigmastanol.

consuming sheep (Shnaider S. et al., 2018; Taylor et al., 2018). Furthermore, archaeological findings close to Lake Chatyr Kol indicated the presence of humans in the area around the lake during the Mesolithic and Neolithic. Ranov and Kydyrov (1969) described findings of stone tools at two archaeological sites at Kok-Aygyr, northeast of Lake Chatyr Kol. The relative ages of these archaeological sites were established by assigning a series of characteristic artifacts to a local culture dated to $9,530 \pm$ 130 a. Furthermore, Ranov (1975) reported findings from the archaeological site Terek-1, $\sim 40 \mathrm{~km}$ east of Lake Chatyr Kol, described as likely Neolithic based on the composition and craftwork of the excavated assemblages.

The Lake Chatyr Kol fecal sterol record does not indicate local human presence during the Early Holocene as the amounts of coprostanol, epicoprostanol, and cholesterol remained near the background values (median values for Phase I: 0.72, 1.19, and $1.72 \mu \mathrm{g} / \mathrm{g}$ d.w., respectively) (Figure 4). Yet, elevated concentrations of $5 \alpha$-cholestanol and $5 \beta$-stigmastanol indicate an increased presence of indigenous higher mammals in the catchment area during the Early Holocene. The first biomarker evidence for an increased occurrence of higher mammals at Lake Chatyr Kol is found at $\sim 10,600$ and $\sim 9,500$ a BP (Figure 4). The occupation by mammals over a prolonged period during the Early Holocene is further supported by generally higher $5 \beta$-stigmastanol concentrations between $\sim 8,300$ and $\sim 8,500$ a BP. More temperate climate conditions in Kyrgyzstan during this time were inferred from analyzing the sediments of Lake Son Kul, located $\sim 125 \mathrm{~km}$ north of Lake Chatyr Kol (Huang et al., 2014; Mathis et al., 2014) and Lake Issyk-Kul, located $\sim 242 \mathrm{~km}$ northeast of Lake Chatyr Kol (Ricketts et al., 2001).

In order to estimate the flux of vegetation remains within the catchment area of Lake Chatyr Kol independently from the fecal biomarkers, we analyzed the concentrations of longchain $n$-alkanes $\left(n \mathrm{C}_{27}, n \mathrm{C}_{29}, n \mathrm{C}_{31}\right) . \quad$ An increase in the concentration of long-chain $n$-alkanes would imply enhanced organic productivity, since these compounds are commonly found in terrestrial sources, such as terrestrial plants and grasses (Eglinton and Hamilton, 1967; Meyers, 2003). Both long-chain $n$-alkanes and arboreal pollen increase at the beginning of the early Holocene (Figure 3). It is therefore likely that more temperate climate conditions promoted the growth of terrestrial vegetation, resulting in improved habitability of the Lake Chatyr Kol catchment area.

\section{Phase II ( 7,600-2,400 a BP)}

The earliest biomolecular evidence of human presence in the Lake Chatyr Kol catchment is provided by significant increases in the concentrations of coprostanol, epicoprostanol, and cholesterol at $\sim 5,900$ a BP and particularly at $\sim 4,800$ a BP (Figure 4). This is further supported by elevated R1 and R2 values (Figure 3). Since 5 $\beta$-stigmastanol concentrations also reveal maximum values at the same time, it is likely that human presence at that time was associated with domesticated livestock. Variations in the concentrations of fecal sterols suggest that the population size of the first human occupancy was low in relation to the human presence at $\sim 4,800$ a $\mathrm{BP}$ as changes in the human and livestock population would inevitably entail changes in the concentrations of fecal sterols being transported to the lake (cf. D’Anjou et al., 2012).

The biomarker evidence for human presence at Lake Chatyr Kol during Phase II coincides with findings of stone tool assemblages from Grotto Semetey situated in the adjoining Arpa river valley dating to $\sim 5,700$ and $\sim 6,180$ cal a BP (Abdykanova, 2014).

Archeological findings of ceramic fragments and radiocarbon dating of animal bones (4,240-3,990 cal a BP) at Chegirtke Cave in southern Kyrgyzstan indicate that humans started to occupy the mountain foothills of the Alay Valley at least during the early Bronze Age (Taylor et al., 2018). Since the excavated bone fragments at this site belong to sheep, goat, and cattle, it can be concluded that they represent a pastoral assemblage of domestic animals (Taylor et al., 2018). This would support our assumption of a livestock-herding human occupancy around Lake Chatyr Kol at $\sim 4,800$ a BP. Evidence of human occupancy during the Bronze Age is provided by archeological excavations at the closely nearby site Aigyrzhal-2 (2,005 $\mathrm{m}$ a.s.l.) in central Kyrgyzstan, $\sim 97 \mathrm{~km}$ northeast of Lake Chatyr Kol (Motuzaite Matuzeviciute et al., 2017). Domestic animal remains, such as horse and ovicaprines, and remains of cereals (grains and chaff), indicate that humans in the Tian Shan mountain valleys developed agricultural interests during this period (Motuzaite Matuzeviciute et al., 2017). Yet, at the high-altitude site Lake Chatyr Kol pollen analysis did not indicate agricultural practice. The oldest directly dated wheat remains in Central Asia have been found in Tasbas, eastern Kazakhstan, and have been dated to $\sim 4,500$ cal a BP (Doumani et al., 2015). Based on archaeobotanical and carbon isotope data of human bones and dating of crop remains found in prehistoric sites in Eurasia, Dong et al. (2017) suggested that western Asian crops spread to eastern Central Asia and northwestern China between 4,500 and 4,000 a BP. Further evidence of early agricultural and herding practice in Central Asia stems from the Eneolithic/Early 
Bronze Age site of Sarazm in northwestern Tajikistan (Frachetti, 2012; Spengler and Willcox, 2013). Sarazm was a sedentary agropastoral settlement, which was occupied from the fourth to the end of the third millenium BC and provides evidence for exchange and trade (Spengler and Willcox, 2013).

Paleoenvironmental studies from Kyrgyzstan indicate rather dry conditions during Phase II. Lauterbach et al. (2014) reported a pronounced dry interval for Lake Son Kul between 4,950 and 3,900 cal a BP. In accordance, a stalagmite record from Uluu2 Cave, $\sim 250 \mathrm{~km}$ west of Lake Chatyr Kol, also suggests dry conditions between 4,700 and 3,900 cal a BP (Wolff et al., 2017). These dry conditions likely entailed the necessity of exploiting new herding grounds and correspondingly affected migration flows. Human settlement and local herding within the catchment area of Lake Chatyr Kol were likely favored by an open landscape and herbaceous vegetation as indicated by pollen data (Figure 3).

Phase II is mainly characterized by a high amount of longchain $n$-alkanes, which is in line with the presence of herbivores in general (Figure 3; R2). The high amounts of the human specific fecal biomarkers, however, cover only a short period of time that is defined by a reduced flux of vegetation remains. Further, pollen data do not indicate significant increases or compositional changes of the local vegetation. We therefore suggest the reported dryness likely influenced the presence of humans at Lake Chatyr Kol rather than an enhanced supply of vegetation resources. As there are no pollen data indicative of agricultural practices, the catchment area of Lake Chatyr Kol was likely inhabited by pastoralists rather than agro-pastoralists.

Concentrations of human-specific fecal sterols returned to background values between $\sim 3,900$ a $\mathrm{BP}$ and $\sim 2,400$ a $\mathrm{BP}$ (Figure 4) and 5 $\beta$-stigmastanol concentrations decreased similarly at $\sim 3,900$ a BP. The decline in the fecal sterol concentrations was probably triggered by a shift to colder climate conditions as reconstructed for Lake Karakul in NE Tajikistan $(\sim 240 \mathrm{~km}$ southwest of Lake Chatyr Kol) at $\sim 3,500 \mathrm{cal} \mathrm{a}$ BP, for Lake Balikun, eastern Tian Shan Mountains, between 4,800 and 3,800 cal a BP (Zhao et al., 2017) and for Lake Qinghai, located in the northeast corner of the Tibet-Qinghai Plateau Qinghai, between 5,000 and 3,500 cal a BP (Hou et al., 2016). 5 $\beta$-Stigmastanol concentrations however increase again shortly afterward to relatively high amounts at $\sim 3,600$ a $\mathrm{BP}$, indicating herbivore activity without a significant presence of human activity.

The latest short-term increase of human-specific fecal sterol concentrations occurred between $\sim 2,500$ and $\sim 2,400$ a BP. As previously observed, this increase is accompanied by a simultaneous increase of $5 \beta$-stigmastanol concentrations, suggesting livestock farming. Interpreting these elevated concentrations in the context of local environmental conditions, they again appear to have contemporaneously occurred to dry climate conditions. For example, a warm and dry episode has been identified at Lake Karakuli, $\sim 240 \mathrm{~km}$ south of Lake Chatyr Kol, between 2,500 and 1,900 cal a BP (Aichner et al., 2015). Pollen data from the Kashgar oasis at the western margin of the Tarim Basin show sparse vegetation cover from 2,620 to 1,750 cal a BP, indicating a relatively dry climate (Zhao et al., 2012). Similarly, Mischke et al. (2010) reported low freshwater inflow and a low lake level for Lake Karakul between 2,600 and $1,900 \mathrm{cal}$ a BP.

\section{Phase III ( 2,300 a BP - Present)}

Phase III is characterized by generally low concentrations of coprostanol, epicoprostanol and cholesterol, suggesting scarce human presence within the catchment area of Lake Chatyr Kol. $5 \beta$-Stigmastanol concentrations remained on an intermediate level between $\sim 1,900$ and $\sim 1,300$ a BP but significantly dropped thereafter (Figure 4).

The economy of Kyrgyzstan largely relies on the agricultural sector and seminomadic lifestyles continue to exist until presentday (Rahimon, 2012). A survey of pastoralists in Kyrgyzstan revealed that in AD 2004 only 12 herding families encamped the vicinity of Lake Chatyr Kol, owning livestock of not more than 12,000 sheep (Farrington, 2005). At present, the basin of Lake Chatyr Kol is little used, with the majority of occupancy occurring during the summer months from June to mid- September (Farrington, 2005). This could explain the low amounts of fecal sterols in the youngest part of the Lake Chatyr Kol sediment record.

\section{Cultural Importance of the Tian Shan}

Being located along the ancient Silk Road, the territory of Kyrgyzstan represented an important corridor for cultural exchange and trade in the past. The Silk Road was a complex network of trade and travel routes, which enabled both cultural interaction and the trading of goods between Central Asia, the Middle East and the Eastern Mediterranean (Hansen, 2012; Yang et al., 2019b). Therefore, it functioned as a "Cultural Bridge" between Asia and Europe (Foltz, 2010; Yang et al., 2019b) and had a profound influence on societal development. Even though the relevance of the Silk Road is conventionally constrained to the second century BC, exchange and migration occurred well before that (Taylor et al., 2019). Archeological studies elucidated that ancient trade and travel routes along this corridor already existed during the Bronze Age (third to second millenium BC) (Frank and Thompson, 2005; Frachetti et al., 2017; Panyushkina et al., 2019), although details about pathways and exact timing are still uncertain.

The progression of mobile pastoralist groups during the Bronze Age is considered to have contributed to the evolvement of high-elevation pathways across the Silk Road, but more research is needed to determine their extent (Frachetti et al., 2017). Nevertheless, interrelations and early diffusions of technologies between mobile pastoralist economies across Eurasia occurred from the third to the second millenium BC (Mei, 2003; Spengler et al., 2014).

This is in good agreement with our observation of elevated fecal sterol amounts at $\sim 4,800$ year. BP, indicating anthropogenic and livestock presence. Indeed, it is suggested that the Tian Shan was already occupied by pastoralists during the Bronze Age (Motuzaite Matuzeviciute et al., 2017). Along with the Pamir, Dzhungar and Altai mountains, the Tian Shan is part of a proposed "Inner Asian Mountain Corridor" (Frachetti, 2012), which promoted the exchange of goods, culture flow (Spengler and Willcox, 2013) and the earliest diffusion of sheep and goat 
pastoralism to inner Asia at 3,500 BC (Frachetti, 2012). Routes of nomadic societies near Lake Chatyr Kol have been indicated by Frachetti et al. (2017), who used flow accumulation modeling to assess migration along the Silk Road. Specifically, the model results revealed a path crossing the Torugart Pass in the south, highlighting the importance of Lake Chatyr Kol as a likely transit stop along herding routes.

Considering that the human-specific fecal sterols in the Lake Chatyr Kol sediment record diminished at $\sim 3,900$ year. BP, it is likely that mobile non-sedentary pastoralists occupied the Lake Chatyr Kol catchment area around $\sim 4,800$ year. BP but later left the area again, probably focusing on other, more habitable regions. The migration from one region to another after the consumption of resources in one area is commonly observed along the Silk Road (Yang et al., 2019b). This does not necessarily entail the collapse of a population, but rather reflects high adaptability and resilience of social groups (Yang et al., 2019b).

In summary, our study indicates human migration in the area around Lake Chatyr Kol as early as during the early Bronze Age, centuries before the establishment of the Silk Road. This reinforces the influence of small-scale migration patterns on the evolution of a macro-scale trade and exchange network (Frachetti et al., 2017).

\section{CONCLUSION}

The present study demonstrates the usefulness of fecal biomarker analyses as a valuable tool to reconstruct temporal anthropogenic presence in an area as an alternative approach in archeological studies. Such biomarker analyses applied to the sediments of Lake Chatyr Kol, Kyrgyzstan reveal a pronounced population evolvement in the Tian Shan at $\sim 4,800$ a BP. Coinciding dry environmental conditions likely increased the accessibility of high-altitude regions and necessitated the exploitation of new herding grounds. This finding suggests climatic change, inter alia, as a potential driver for human migration and underlines the ability of early humans to adapt to variable environmental conditions. Migration through the high-altitude terrains of the Tian Shan reveals its cultural importance as an early travel corridor during the Bronze Age. As one of the rare high-altitude sites providing evidence of early pastoralists, Lake Chatyr Kol is

\section{REFERENCES}

Abdykanova, A. (2014). New data on mesolithic and neolithic in Kyrgyzstan: a brief review. Bull. IICAS Pub. Int. Inst. Centr. Asian Stud. 20, 5-19.

Abuduwaili, J., Issanova, G., and Saparov, G. (2019). Lakes in Kyrgyzstan, Hydrology and Limnology of Central Asia. Singapore: Springer, 288-294. doi: 10.1007/978981-13-0929-8

Agatova, A. R., Nepop, R. K., Slyusarenko, I. Y., Myglan, V. S., Nazarov, A. N., and Barinov, V. V. (2014). Glacier dynamics, palaeohydrological changes and seismicity in southeastern Altai (Russia) and their influence on human occupation during the last 3000 years. Quat. Int. 324, 6-19. doi: 10.1016/j. quaint.2013.07.018

Aichner, B., Feakins, S. J., Lee, J. E., Herzschuh, U., and Liu, X. (2015). Highresolution leaf wax carbon and hydrogen isotopic record of the late Holocene of great importance for the understanding of the human history and migration in Eurasia.

\section{DATA AVAILABILITY STATEMENT}

The datasets generated for this study are available on request to the corresponding author.

\section{AUTHOR CONTRIBUTIONS}

GG conceived the research idea. SL conducted the field work. MS contributed pollen data. JK and JM generated the age model. NS conducted laboratory analysis and data analysis with support from SS and CY. NS prepared the manuscript. All authors discussed the data and improved the manuscript.

\section{FUNDING}

This study was supported by the BMBF-funded research projects CADY (Central Asian Climate Dynamics, Grant No. 03G0813) and CAHOL (Central Asian Holocene Climate, Grant No. 03G0864). NS acknowledges the Max Planck Society and the International Max Planck Research School for Global Biogeochemical Cycles (IMPRS-gBGC) for additional project funding.

\section{ACKNOWLEDGMENTS}

The authors thank Michael Köhler, Sylvia Pinkerneil, Roman Witt, and Robert Schedel for their help during field work and Stefanie Garz for her help during pollen analysis.

\section{SUPPLEMENTARY MATERIAL}

The Supplementary Material for this article can be found online at: https://www.frontiersin.org/articles/10.3389/feart. 2020.00020/full\#supplementary-material

paleoclimate in arid Central Asia. Clim. Past 11, 619-633. doi: 10.5194/cp-11619-2015

Aizen, E. M., Aizen, V. B., Melack, J. M., Nakamura, T., and Ohta, T. (2001). Precipitation and atmospheric circulation patterns at mid-latitudes of Asia. Int. J. Climatol. 21, 535-556. doi: 10.1002/joc.626

Aizen, V., Aizen, E., and Melack, J. (1995). Climate, snow cover, glaciers, and runoff in the Tien Shan, Central Asia. J. Am. Water Resour. Bull. 31, 1113-1129. doi: 10.1111/j.1752-1688.1995.tb03426.x

Aizen, V., Aizen, E., Melack, J., and Dozier, J. (1997). Climatic and hydrologic changes in the Tien Shan, Central Asia. J. Clim. 10, 1393-1404. doi: 10.1175/ 1520-04421997010<1393:CAHCIT<2.0.CO;2

Appleby, P. G. (2002). "Chronostratigraphic techniques in recent sediments," in Tracking Environmental Change Using Lake Sediments, eds W. M. Last, and J. P. Smol, (Dordrecht: Springer), 171-203. doi: 10.1007/0-306-47669-x_9 
Appleby, P. G., and Oldfield, F. (1978). The calculation of lead-210 dates assuming a constant rate of supply of unsupported $210 \mathrm{~Pb}$ to the sediment. Catena $5,1-8$. doi: 10.1016/S0341-8162(78)80002-2

Bae, C. J., Douka, K., and Petraglia, M. D. (2017). On the origin of modern humans: Asian perspectives. Science 358:eaai9067. doi: 10.1126/science.aai9067

Baeten, J., Marinova, E., De Laet, V., Degryse, P., De Vos, D., and Waelkens, M. (2012). Faecal biomarker and archaeobotanical analyses of sediments from a public latrine shed new light on ruralisation in Sagalassos, Turkey. J. Archaeol. Sci. 39, 1143-1159. doi: 10.1016/j.jas.2011.12.019

Battistel, D., Piazza, R., Argiriadis, E., Marchiori, E., Radaelli, M., and Barbante, C. (2015). GC-MS method for determining faecal sterols as biomarkers of human and pastoral animal presence in freshwater sediments. Anal. Bioanal. Chem. 407, 8505-8514. doi: 10.1007/s00216-015-8998-2

Beer, R., Heiri, O., and Tinner, W. (2007). Vegetation history, fire history and lake development recorded for 6300 years by pollen, charcoal, loss on ignition and chironomids at a small lake in southern Kyrgyzstan (Alay Range. Central Asia). Holocene 17, 977-985. doi: 10.1177/0959683607082413

Berglund, B. E., and Ralska-Jasiewiczowa, M. (1986). "Pollen analysis and pollen Diagrams," in Handbook of Holocene Palaeoecology and Palaeohydrology, ed. B. E. Berglund, (Chichester: Wiley), 455-484.

Beug, H. J. (2004). Leitfaden der Pollenbestimmung für Mitteleuropa und Angrenzende Gebiete, 21. Munich: Dr. Friedrich Pfeil.

Birk, J. J., Teixeira, W. G., Neves, E. G., and Glaser, B. (2011). Faeces deposition on Amazonian Anthrosols as assessed from 5 $\beta$-stanols. J. Archaeol. Sci. 38, 1209-1220. doi: 10.1016/j.jas.2010.12.015

Brantingham, P. J., Xing, G., Madsen, D. B., Rhode, D., Perreault, C., van der Woerd, J., et al. (2013). Late occupation of the high-elevation northern Tibetan Plateau based on cosmogenic, luminescence, and radiocarbon ages. Geoarchaeology 28, 413-431. doi: 10.1002/gea.21448

Bronk Ramsey, C. (1995). Radiocarbon calibration and analysis of stratigraphy: the OxCal program. Radiocarbon 37, 425-430. doi: 10.1017/s003382220003 0903

Bull, I. D., Elhmmali, M. M., Roberts, D. J., and Evershed, R. P. (2003). The application of steroidal biomarkers to track the abandonment of a Roman wastewater course at the Agora (Athens, Greece). Archaeometry 45, 149-161. doi: 10.1111/1475-4754.00101

Bull, I. D., Evershed, R. P., and Betancourt, P. P. (2001). An organic geochemical investigation of the practice of manuring at a Minoan site on Pseira Island, Crete. Geoarchaeology 16, 223-242. doi: 10.1002/1520-6548(200102)16:2<223:: aid-gea1002<3.0.co;2-7

Bull, I. D., Lockheart, M. J., Elhmmali, M. M., Roberts, D. J., and Evershed, R. P. (2002). The origin of faeces by means of biomarker detection. Environ. Int. 27, 647-654. doi: 10.1016/s0160-4120(01)00124-6

Bull, I. D., Simpson, I. A., Van Bergen, P. F., and Evershed, R. P. (1999). Muck ' $n$ ' molecules: organic geochemical methods for detecting ancient manuring. Antiquity 73, 86-96. doi: 10.1017/s0003598x0008786x

D’Anjou, R. M., Bradley, R. S., Balascio, N. L., and Finkelstein, D. B. (2012). Climate impacts on human settlement and agricultural activities in northern Norway revealed through sediment biogeochemistry. Proc. Natl. Acad. Sci. U.S.A. 109, 20332-20337. doi: 10.1073/pnas.1212730109

Daughton, C. G. (2012). Real-time estimation of small-area populations with human biomarkers in sewage. Sci. Total Environ. 414, 6-21. doi: 10.1016/j. scitotenv.2011.11.015

de Bar, M. W., Ullgren, J. E., Thunnell, R. C., Wakeham, S. G., Brummer, G.J. A., Stuut, J.-B. W., et al. (2019). Long-chain diols in settling particles in tropical oceans: insights into sources, seasonality and proxies. Biogeosciences 16, 1705-1727. doi: 10.5194/bg-16-1705-2019

DeMenocal, P. B. (2001). Cultural responses to climate change during the late holocene. Science 292, 667-673. doi: 10.1126/science.1059827

Dong, G., Jia, X., An, C., Chen, F., Zhao, Y., Tao, S., et al. (2012). Mid-Holocene climate change and its effect on prehistoric cultural evolution in eastern Qinghai Province, China. Quat. Res. 77, 23-30. doi: 10.1016/j.yqres.2011.10.004

Dong, G., Yang, Y., Han, J., Wang, H., and Chen, F. (2017). Exploring the history of cultural exchange in prehistoric Eurasia from the perspectives of crop diffusion and consumption. Sci. China Earth Sci. 60, 1110-1123. doi: 10.1007/s11430016-9037-x

Doumani, P., Frachetti, M., Beardmore, R., Schmaus, T., Spengler, R. N. III, and Mar'yashev, A. (2015). Burial ritual, agriculture, and craft production among
Bronze age pastoralists at Tasbas (Kazakhstan). Archaeol. Res. Asia 1-2, 17-32. doi: 10.1016/j.ara.2015.01.001

Eglinton, G., and Hamilton, R. (1967). Leaf epicuticular waxes. Science 156, 1322-1335. doi: 10.1126/science.156.3780.1322

Engels, S., van Oostrom, R., Cherli, C., Dungait, J. A. J., Jansen, B., van Aken, J. M., et al. (2018). Natural and anthropogenic forcing of Holocene lake ecosystem development at lake Uddelermeer (The Netherlands). J. Paleolimnol. 59, 329-347. doi: 10.1007/s10933-017-0012-x

Evershed, R. P., and Bethell, P. H. (1996). Application of multimolecular biomarker techniques to the identification of fecal material in archaeological soils and sediments. Archaeol. Chem. 625, 157-172. doi: 10.1021/bk-1996-0625.ch013

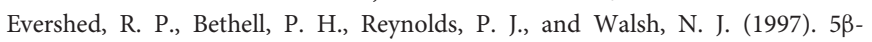
stigmastanol and related $5 \beta$-stanols as biomarkers of manuring: analysis of modern experimental material and assessment of the archaeological potential. J. Archaeol. Sci. 24, 485-495. doi: 10.1006/jasc.1996.0132

Eyssen, H. J., Parmentier, G. G., Compernolle, F. C., De Pauw, G., and PiessensDenef, M. M. (1973). Biohydrogenation of sterols by Eubacterium ATCC 21,408 - nova species. Eur. J. Biochem. 36, 411-421. doi: 10.1111/j.1432-1033. 1973.tb02926.x

Farrington, J. D. (2005). De-development in Eastern Kyrgyzstan and persistence of semi-nomadic livestock herding. Nomad. Peoples 9, 171-197. doi: 10.3167/ 082279405781826191

Flohr, P., Fleitmann, D., Matthews, R., Matthews, W., and Black, S. (2016). Evidence of resilience to past climate change in Southwest Asia: early farming communities and the 9.2 and 8.2 ka events. Quat. Sci. Rev. 136, 23-39. doi: 10.1016/j.quascirev.2015.06.022

Foltz, R. (2010). Religions of the Silk Road: Premodern Patterns of Globalization. New York, NY: Palgrave Macmillan.

Frachetti, M. D. (2012). Multiregional emergence of mobile pastoralism and nonuniform institutional complexity across Eurasia. Curr. Anthropol. 53, 2-38. doi: 10.1086/663692

Frachetti, M. D., Smith, C. E., Traub, C. M., and Williams, T. (2017). Nomadic ecology shaped the highland geography of Asia's Silk Roads. Nature 543, 193-198. doi: 10.1038/nature21696

Frank, A. G., and Thompson, W. R. (2005). Afro-Eurasian bronze age economic expansion and contraction revisited. J. World Hist. 16, 115-172. doi: 10.1353/ jwh.2005.0142

Gea, J., Sampedro, M. C., Vallejo, A., Polo-Diaz, A., Goicolea, M. A., FernandezEraso, J., et al. (2017). Characterization of ancient lipids in prehistoric organic residues: chemical evidence of livestock-pens in rock-shelters since early neolithic to bronze age. J. Sep. Sci. 40, 4549-4562. doi: 10.1002/jssc.201700692

Grimalt, J. O., Fernandez, P., Bayona, J. M., and Albaiges, J. (1990). Assessment of fecal sterols and ketones as indicators of urban sewage inputs to coastal waters. Environ. Sci. Technol. 24, 357-363. doi: 10.1021/es00073a011

Hansen, V. (2012). The Silk Road: A New History. Oxford: Oxford University Press. Hessl, A. E., Leland, C., Saladyga, T., and Byambasuren, O. (2017). "Hydraulic cities, colonial catastrophes, and nomadic empires: human-environment interactions in Asia," in Dendroecology: Tree-Ring Analyses Applied to Ecological Studies, eds M. M. Amoroso, L. D. Daniels, P. J. Baker, and J. J. Camarero, (Cham: Springer Internel Publishing), 345-363. doi: 10.1007/978-3-31961669-8_15

Hou, J., Huang, Y., Zhao, J., Liu, Z., Colman, S., and An, Z. (2016). Large Holocene summer temperature oscillations and impact on the peopling of the northeastern Tibetan Plateau. Geophys. Res. Lett. 43, 1323-1330.

Huang, X., Oberhänsli, H., von Suchodoletz, H., Prasad, S., Sorrel, P., Plessen, B., et al. (2014). Hydrological changes in western Central Asia (Kyrgyzstan) during the Holocene as inferred from a palaeolimnological study in lake Son Kul. Quat. Sci. Rev. 103, 134-152. doi: 10.1016/j.quascirev.2014.09.012

Ilyasov, S., Zabenko, O., Gaydamak, N., Kirilenko, A., Myrsaliev, N., and Shevchenko, V. (2013). Climate profile of the Kyrgyz Republic. Vol. 99. Bishkek: The United Nations Development Programme.

Kinder, M., Tylmann, W., Bubak, I., Fiłoc, M., Gąsiorowski, M., Kupryjanowicz, M., et al. (2019). Holocene history of human impacts inferred from annually laminated sediments in Lake Szurpiły, northeast Poland. J. Paleolimnol. 61, 419-435. doi: 10.1007/s10933-019-00068-2

Koppes, M., Gillespie, A. R., Burke, R. M., Thompson, S. C., and Stone, J. (2008). Late quaternary glaciation in the Kyrgyz Tien Shan. Quat. Sci. Rev. 27, 846-866. doi: 10.1016/j.quascirev.2008.01.009 
Konopka, T. (2019). UMAP: Uniform Manifold Approximation and Projection. R Package Version 0.2.3.1.

Kudo, A., Zheng, J., Koerner, R. M., Fisher, D. A., Santry, D. C., Mahara, Y., et al. (1998). Global transport rates of $137 \mathrm{Cs}$ and $239+240 \mathrm{Pu}$ originating from the Nagasaki A-bomb in 1945 as determined from analysis of Canadian Arctic ice cores. J. Environ. Radioact. 40, 289-298. doi: 10.1016/S0265-931X(97)00023-4

Lauterbach, S., Witt, R., Plessen, B., Dulski, P., Prasad, S., Mingram, J., et al. (2014). Climatic imprint of the mid-latitude Westerlies in the Central Tian Shan of Kyrgyzstan and teleconnections to North Atlantic climate variability during the last 6000 years. Holocene 24, 970-984. doi: 10.1177/0959683614 534741

Leeming, R., Ball, A., Ashbolt, N., and Nichols, P. (1996). Using faecal sterols from humans and animals to distinguish faecal pollution in receiving waters. Water Res. 30, 2893-2900. doi: 10.1016/s0043-1354(96)00011-5

Leeming, R., and Nichols, P. (1996). Concentrations of coprostanol that correspond to existing bacterial indicator guideline limits. Water Res. 30, 2997-3006. doi: 10.1016/s0043-1354(96)00212-6

Ma, Y., Liu, K. -b, Feng, Z., Sang, Y., Wang, W., and Sun, A. (2008). A survey of modern pollen and vegetation along a south-north transect in Mongolia. J. Biogeogr. 35, 1512-1532. doi: 10.1111/j.1365-2699.2007.01871.x

Macdonald, I. A., Bokkenheuser, V. D., Winter, J., McLernon, A. M., and Mosbach, E. H. (1983). Degradation of steroids in the human gut. J. Lipid Res. 24, 675-700.

Madsen, D. B., Haizhou, M., Brantingham, P. J., Xing, G., Rhode, D., Haiying, Z., et al. (2006). The late upper paleolithic occupation of the northern Tibetan Plateau margin. J. Archaeol. Sci. 33, 1433-1444. doi: 10.1016/j.jas.2006.01.017

Marcott, S. A., Shakun, J. D., Clark, P. U., and Mix, A. C. (2013). A reconstruction of regional and global temperature for the past 11,300 years. Science 339, 1198-1201. doi: 10.1126/science. 1228026

Martins, C. D. C., Fillmann, G., and Montone, R. C. (2007). Natural and anthropogenic sterols inputs in surface sediments of Patos Lagoon, Brazil. J. Braz. Chem. Soc. 18, 106-115. doi: 10.1590/s0103-50532007000100012

Mathis, M., Sorrel, P., Klotz, S., Huang, X., and Oberhänsli, H. (2014). Regional vegetation patterns at lake Son Kul reveal Holocene climatic variability in central Tien Shan (Kyrgyzstan, Central Asia). Quat. Sci. Rev. 89, 169-185. doi: 10.1016/j.quascirev.2014.01.023

McInnes, L., Healy, J., Saul, N., and Großberger, L. (2018). UMAP: uniform manifold approximation and projection. J. Open Source Softw. 3:861. doi: 10. 21105/joss.00861

Mei, J. (2003). "Qijia and seima-turbino: the question of early contacts betweenNorthwest China and the Eurasian steppe", in Bulletin of the Museum of FarEastern Antiquities. Vol. 75, A. B. Damania, J. Valkoun, et al. (Stockholm: Museum of Far Eastern Antiquities), 31-54.

Meyer, M. C., Aldenderfer, M. S., Wang, Z., Hoffmann, D. L., Dahl, J. A., Degering, D., et al. (2017). Permanent human occupation of the central Tibetan Plateau in the early Holocene. Science 355, 64-67. doi: 10.1126/science.aag0357

Meyers, P. A. (2003). Applications of organic geochemistry to paleolimnological reconstructions: a summary of examples from the Laurentian Great Lakes. Org. Geochem. 34, 261-289. doi: 10.1016/s0146-6380(02)00168-7

Mischke, S., Rajabov, I., Mustaeva, N., Zhang, C., Herzschuh, U., Boomer, I., et al. (2010). Modern hydrology and late Holocene history of Lake Karakul, eastern Pamirs (Tajikistan): a reconnaissance study. Palaeogeogr. Palaeoclimatol. Palaeoecol. 289, 10-24. doi: 10.1016/j.palaeo.2010.02.004

Mosello, B. (2015). The Syr Darya River Basin, How to Deal with Climate Change? Bern: Springer International Publishing, 117-162. doi: 10.1007/978-3-31915389-6_5

Motuzaite Matuzeviciute, G., Preece, R. C., Wang, S., Colominas, L., Ohnuma, K., Kume, S., et al. (2017). Ecology and subsistence at the Mesolithic and Bronze Age site of Aigyrzhal-2, Naryn valley, Kyrgyzstan. Quat. Int. 437, 35-49. doi: $10.1016 /$ j.quaint.2015.06.065

Ortiz, J. E., Sánchez-Palencia, Y., Torres, T., Domingo, L., Mata, M. P., Vegas, J., et al. (2016). Lipid biomarkers in Lake Enol (Asturias, Northern Spain): coupled natural and human induced environmental history. Org. Geochem. 92, 70-83. doi: 10.1016/j.orggeochem.2015.12.005

Ossendorf, G., Groos, A. R., Bromm, T., Tekelemariam, M. G., Glaser, B., Lesur, J., et al. (2019). Middle stone age foragers resided in high elevations of the glaciated Bale Mountains, Ethiopia. Science 365, 583-587. doi: 10.1126/science.aaw 8942
Panyushkina, I. P., Macklin, M. G., Toonen, W. H. J., and Meko, D. M. (2019). "Water Supply and Ancient Society in the Lake Balkhash Basin: Runoff Variability along the Historical Silk Road," in Socio-Environmental Dynamics along the Historical Silk Road, eds L. Yang, H.-R. Bork, X. Fang, and S. Mischke, (Cham: Springer), 379-410. doi: 10.1007/978-3-030-00728-7_18

Qin, F., Wang, Y.-F., Ferguson, D. K., Chen, W.-L., Li, Y.-M., Cai, Z., et al. (2015). Utility of surface pollen assemblages to delimit eastern Eurasian steppe types. PLoS One 10:e0119412. doi: 10.1371/journal.pone.0119412

R Core Team (2019). R: A Language and Environment for Statistical Computing. Vienna: R Foundation for Statistical Computing.

Rademaker, K., Hodgins, G., Moore, K. M., Zarrillo, S., Miller, C. E., Bromley, G. R. M., et al. (2014). Paleoindian settlement of the high-altitude Peruvian Andes. Science 346, 466-469. doi: 10.5061/dryad.96g44

Rahimon, R. M. (2012). "Evolution of land use in pastoral culture in Central Asia with special reference to Kyrgyzstan and Kazakhstan," in Rangeland Stewardship in Central Asia, ed. V. Squires, (Dordrecht: Springer), 51-67. doi: 10.1007/97894-007-5367-9_3

Ranov, V. A. (1975). Pamir i problema zaseleniya vîsokogoriyi Azii chelovekom kamennogo veka. Stranî i narodî Vostoka 17, 136-157.

Ranov, V. A., and Kydyrov, S. A. (1969). Nakhodki kamennogo veka u ozera Chatyrkel. Izvestiya Akad. Nauk Tadzhykskoi SSR 1, 32-35.

Reille, M. (1995-1999). Pollen et spores d'Europe et d'Afrique du Nord. Marseille: Laboratoire de Botanique Historique et Palynologie.

Reimer, P. J., Bard, E., Bayliss, A., Beck, J. W., Blackwell, P. G., Ramsey, C. B., et al. (2013). IntCal13 and marine13 radiocarbon age calibration curves 0-50,000 years cal BP. Radiocarbon 55, 1869-1887. doi: 10.2458/azu_js_rc.55.16947

Richey, J. N., and Tierney, J. E. (2016). GDGT and alkenone flux in the northern Gulf of Mexico: implications for the TEX86 and UK'37 paleothermometers. Paleoceanography 31, 1547-1561. doi: 10.1002/2016pa003032

Ricketts, R. D., Johnson, T. C., Brown, E. T., Rasmussen, K. A., and Romanovsky, V. V. (2001). The Holocene paleolimnology of Lake Issyk-Kul, Kyrgyzstan: trace element and stable isotope composition of ostracodes. Palaeogeogr. Palaeoclimatol. Palaeoecol. 176, 207-227. doi: 10.1016/s0031-0182(01)00339-x

Rogge, W. F., Medeiros, P. M., and Simoneit, B. R. T. (2006). Organic marker compounds for surface soil and fugitive dust from open lot dairies and cattle feedlots. Atmos. Environ. 40, 27-49. doi: 10.1016/j.atmosenv.2005.07.076

Ryan, W. B .F., Carbotte, S. M., Coplan, J. O., O’Hara, S., Melkonian, A., Arko, R., et al. (2009). Global Multi-Resolution Topography synthesis. Geochemistry, Geophysics, Geosystems 10. doi: 10.1029/2008gc002332

Shnaider, S., Taylor, W. T., Abdykanova, A., Kolobova, K., and Krivoshapkin, A. (2018). Evidence for early human occupation at high altitudes in western Central Asia: the Alay site. Antiquity 92, 1-7. doi: 10.15184/aqy.2018.94

Shnaider, S. V., Kolobova, K. A., Filimonova, T. G., Taylor, W., and Krivoshapkin, I. (2018). New insights into the Epipaleolithic of western Central Asia: the Tutkaulian complex. Quat. Int. (in press). doi: 10.1016/j.quaint.2018.10.001

Shnitnikov, A. V., Livja, A. A., Berdovskaya, G. N., and Sevastianov, D. V. (1978). Paleolimnology of chatyrkel lake (Tien-shan). Pol. Arch. Hydrobiol. 25, 383-390.

Spengler, R., Frachetti, M., Doumani, P., Rouse, L., Cerasetti, B., Bullion, E., et al. (2014). Early agriculture and crop transmission among bronze age mobile pastoralists of Central Eurasia. Proc. R. Soc. B Biol. Sci. 281:20133382. doi: 10.1098/rspb.2013.3382

Spengler, R. N., and Willcox, G. (2013). Archaeobotanical results from Sarazm, Tajikistan, an early bronze age settlement on the edge: agriculture and exchange. Environ. Archaeol. 18, 211-221. doi: 10.1179/1749631413y.0000000008

Taft, J. B., Phillippe, L. R., Dietrich, C. H., and Robertson, K. R. (2011). Grassland composition, structure, and diversity patterns along major environmental gradients in the Central Tien Shan. Plant Ecol. 212, 1349-1361. doi: 10.1007/ s11258-011-9911-5)

Taylor, W., Shnaider, S., Abdykanova, A., Fages, A., Welker, F., Irmer, F., et al. (2018). Early pastoral economies along the Ancient Silk Road: biomolecular evidence from the Alay Valley. Kyrgyzstan. PLoS One 13:e0205646. doi: 10.1371/ journal.pone. 0205646

Taylor, W. T. T., Shnaider, S., Spengler, R., Orlando, L., Abdykanova, A., and Krivoshapkin, A. (2019). Investigating ancient animal economies and exchange in Kyrgyzstan's Alay Valley. Antiquity 93, 1-5. doi: 10.15184/aqy.2019.4

Thienemann, M., Masi, A., Kusch, S., Sadori, L., John, S., Francke, A., et al. (2017). Organic geochemical and palynological evidence for Holocene natural 
and anthropogenic environmental change at Lake Dojran (Macedonia/Greece). Holocene 27, 1103-1114. doi: 10.1177/0959683616683261

Thorpe, A., van Anrooy, R., Niyazov, B. N., Sarieva, M. K., Valbo-Jørgensen, J., and Millar, A. M. (2009). The collapse of the fisheries sector in Kyrgyzstan: an analysis of its roots and its prospects for revival. Commu. Post Commun. Stud. 42, 141-163. doi: 10.1016/j.postcomstud.2009.02.007

van der Maaten, L., and Hinton, G. (2008). Visualizing data using t-SNE. J. Mach. Learn. Res. 9, 2579-2605.

Wakeham, S. G. (1989). Reduction of stenols to stanols in particulate matter at oxic-anoxic boundaries in sea water. Nature 342, 787-790. doi: 10.1038/ $342787 \mathrm{a} 0$

Wang, C., Xu, J., Chen, Y., Bai, L., and Chen, Z. (2017). A hybrid model to assess the impact of climate variability on streamflow for an ungauged mountainous basin. Clim. Dyn. 50, 2829-2844. doi: 10.1007/s00382-017-3775-x

White, A. J., Stevens, L. R., Lorenzi, V., Munoz, S. E., Lipo, C. P., and Schroeder, S. (2018). An evaluation of fecal stanols as indicators of population change at Cahokia, Illinois. J. Archaeol. Sci. 93, 129-134. doi: 10.1016/j.jas.2018.03.009

Wickham, H. (2016). ggplot2: Elegant Graphics for Data Analysis. New York: Springer. ISBN: 978-3-319-24277-4

Wolff, C., Plessen, B., Dudashvilli, A. S., Breitenbach, S. F. M., Cheng, H., Edwards, L. R., et al. (2017). Precipitation evolution of Central Asia during the last 5000 years. Holocene 27, 142-154. doi: 10.1177/0959683616652711

Wright, S. M., Howard, B. J., Strand, P., Nylén, T., and Sickel, M. A. K. (1999). Prediction of 137Cs deposition from atmospheric nuclear weapons tests within the Arctic. Environ. Pollut. 104, 131-143. doi: 10.1016/S0269-7491(98)00140-7

Yang, L. E., Bork, H.-R., Fang, X., and Mischke, S. (2019a). Socio-Environmental Dynamics along the Historical Silk Road. Cham: Springer. ISBN: 978-3-03000728-7.
Yang, L. E., Bork, H.-R., Fang, X., Mischke, S., Weinelt, M., and Wiesehöfer, J. (2019b). "On the paleo-climatic/environmental impacts and socio-cultural system resilience along the Historical Silk Road," in Socio-Environmental Dynamics along the Historical Silk Road eds L. Yang, H.-R. Bork, X. Fang, and S. Mischke, (Cham: Springer), 3-22. doi: 10.1007/978-3-030-00728-7_1

Zhang, X. L., Ha, B. B., Wang, S. J., Chen, Z. J., Ge, J. Y., Long, H., et al. (2018). The earliest human occupation of the high-altitude Tibetan Plateau 40 thousand to 30 thousand years ago. Science 326, 1049-1051. doi: 10.1126/science.aat8824

Zhao, J., An, C.-B., Huang, Y., Morrill, C., and Chen, F.-H. (2017). Contrasting early Holocene temperature variations between monsoonal East Asia and westerly dominated Central Asia. Quat. Sci. Rev. 178, 14-23. doi: 10.1016/j. quascirev.2017.10.036

Zhao, K., Li, X., Dodson, J., Atahan, P., Zhou, X., and Bertuch, F. (2012). Climatic variations over the last $4000 \mathrm{cal} \mathrm{yr} \mathrm{BP}$ in the western margin of the Tarim Basin, Xinjiang, reconstructed from pollen data. Palaeogeogr. Palaeoclimatol. Palaeoecol. 32, 16-23. doi: 10.1016/j.palaeo.2012.01.012

Conflict of Interest: The authors declare that the research was conducted in the absence of any commercial or financial relationships that could be construed as a potential conflict of interest.

Copyright (c) 2020 Schroeter, Lauterbach, Stebich, Kalanke, Mingram, Yildiz, Schouten and Gleixner. This is an open-access article distributed under the terms of the Creative Commons Attribution License (CC BY). The use, distribution or reproduction in other forums is permitted, provided the original author(s) and the copyright owner(s) are credited and that the original publication in this journal is cited, in accordance with accepted academic practice. No use, distribution or reproduction is permitted which does not comply with these terms. 